\title{
Research on Beautiful Rural Construction Based on SWOT Analysis-A Case Study of Dayu Village in Yongchun County
}

\author{
LIN Hou ${ }^{1, a,{ }^{*}}$, LV Wanlu ${ }^{1, b}$ \\ ${ }^{1}$ Xiamen University of Technology School of Economy and Management, Xiamen, Fujian, China \\ a33811873@qq.com, b851298992@qq.com \\ ${ }^{*}$ Corresponding author
}

Keywords: SWOT analysis, beautiful village, Dayu Village.

\begin{abstract}
Beautiful rural areas are important parts of beautiful China. Under "new normal", the beautiful rural construction creates an upsurge throughout the nation. Based on SWOT analysis, the thesis takes Dayu Village in Wulijie Town, Yongchun County, Quanzhou City, Fujian Province as an example to make a comprehensive and systematic analysis on strengths, weaknesses, opportunities and threats of Dayu Village's beautiful rural construction. According to the analysis, the thesis proposes to strengthen villages through talents and attach importance to the construction of talent think tank, diversify investment strategy to give full play to the funds integration, implement brand marketing strategy to expand sales channels of products and carry out the "Internet + " strategy to vigorously promote rural tourism.
\end{abstract}

\section{Introduction}

The $18^{\text {th }}$ National Congress of the CPC lifted ecological civilization to the same strategic height with economy, politics, culture and society. It emphasized the overall plan for promoting economic, political, cultural, social, and ecological progress and formally put forward the idea to endeavor to build beautiful China and realize the sustainable development of the Chinese Nation. The beautiful rural construction is the premise and foundation of building beautiful China, as well as an significant measure to realize the idea of building beautiful China. Moreover, it is also a new project and carrier to promote the construction of new socialist villages and boost the construction of ecological civilization.

\section{Overview of Dayu Village}

Dayu Village is located in the northwest of Wulijie Town, Yongcun County, Quanzhou City, Fujian Province, $6 \mathrm{~km}$ away from Yongcun County. It has an average elevation of more than 200 meters. As it belongs to subtropical maritime monsoon climate, Dayu Village has a mild climate with plenty of rainfall and an average temperature of $17-20.5^{\circ} \mathrm{C}$. It covers a geographical area of $2.76 \mathrm{sq} . \mathrm{km}$., among which 16.7 hectares are arable land and 58 hectares are mountain area. Most of the villagers plant ponkan, big tangerine, cane shoot, pear Chihuali, and etc.

\section{SWOT analysis of beautiful rural construction in Dayu Village}

\subsection{Strengths analysis}

\subsubsection{Solid construction foundation}

Dayu Village successively invested RMB 1.65 million to improve its infrastructure. Roads were widened, hardened, greened, beautified and completely renovated. 11 bus intersections were established. 6 roadside attractions were created. 85 street lamps were erected. The goal of lightening central village and main corners has basically realized. The "drinking water project" was implemented. 2 slow filters and a impounding reservoir with capacity of 50 cubic meters were constructed. The penetration rate of tap water reached $100 \%$. Recreational and leisure sites were newly established. 1 culture park, 2 farmer park and 1 rest square with stone piles and wooden piles 
for basic training of Whine Crane Fist were constructed. Two wooden balconies were built in central village, where one can enjoy a panoramic view of the county.

\subsubsection{Unique cultural resources}

With unique Kongfu culture resources, Dayu Village is the birthplace of Yongchun Whine Crane Fist. On June 15th, 2002, Xi Jinping, then-governor of Fujian Province came to Dayu Village to inspect the new rural construction. He watched the performance of Whine Crane Fist and made important instructions on development of ecological environment and old villages reconstruction. He said:"The new rural construction should be tailored to the local condition. It is better if the culture of Whine Crane Fist is combined to show its own feature". After that, Dayu Village starts to excavate cultural resources of beautiful rural construction and devote to promote and develop White Crane Fist culture. On one hand, landscape walls displaying Yongchun Whine Crane Fist culture were built. History center and training center of Whine Crane Fist were built at the entrance to the village. The cartoon image and folk adage of Yongchun White Crane Fist were drawn on outer walls of some rural buildings and equipment of Whine Crane Fist were arranged over doorways and on both sides of the main road. When visitors arrive, they can enjoy a strong atmosphere of martial arts culture. On the other hand, since 2009, "White Crane Fist Culture Festival" has been held on the 24th day of the sixth lunar month in each year. Successors, scholars and experts of Whine Crane Fist are invited to participate and make friends through martial arts, so as to promote and develop Whine Crane Fist culture.

\subsubsection{Good social reputation}

With years of effort, Dayu Village was honored with titles like "China's No.1 Wing Chun Village", "Featured Chinese Village", "National Livable Demonstration Village", "Fujian Health Village", "Fujian Eco Village”, “ Typical Model of Fujian Villages' Comprehensive Improvement(Beautiful Rural Construction)" and "Quanzhou Beautiful Village", attracting thousands of tourists with its good social reputation ${ }^{[1]}$.

\subsection{Weaknesses analysis}

\subsubsection{Simple sales channels of agricultural and sideline products}

Dayu Village abounds in famous, special and high quality fruits including ponkan, big tangerine, pear Chihuali, orange, etc. But for poor transportation and narrow highways, purchasers seldom come for bulk purchase. Villagers can only market their own products while unsaleable part be left to rot in the garden. The investigation result demonstrates that Dayu Village still remains its self-subsistence peasant economy. Their agricultural products are good in quality. But without unified planning and management as well as specialized publicity of their features, the sales channels of agricultural and sideline products are too simple, leading to inconsiderable income increase of villagers.

\subsubsection{Lack of good publication}

Yongchun White Crane fist is the most outstanding feature and the key of publication of Dayu Village. An increasing number of people are using Internet to have access to various information, and a beautiful village should also try its best to make good use of internet publication. In an investigation, only $19 \%$ of tourists learn about Dayu Village through action movie "The Scroll of the Wing Chun White Crane" and Quanzhou TV's "Journey to Villages - Dayu Village", which demonstrates insufficient publication effects from online channels like movies and animations. The survey about which online platform does tourists want Dayu Village to have shows that $25.6 \%$ of tourists hope a website can be built, 23.54\% hope a WeChat Public Platform can be established, $16.67 \%$ hope a micro-blog will be available, and $14.4 \%$ hope a QQ account to be opened. Thus it can be seen that, it is urgent for Dayu village to adopt multi-channel and full-scale online publication of its beautiful rural construction by establishing platforms including website, WeChat, micro-blog, post bar, QQ and so on.

\subsection{Opportunities analysis}

The $18^{\text {th }}$ National Congress of the CPC put forward the strategic objective of promoting the construction of ecological civilization and building a beautiful China, and Fujian Provincial Party 
Committee and Provincial Government also regard building a beautiful Fujian with rich life and ecological beauty as general requirements for construction and development. These top-level development ideas point out the direction for development of beautiful villages, and Dayu Village is embracing its favorable policy opportunities for beautiful rural construction. In 2016, Fujian province invested RMB 16 billion for beautiful rural construction acceleration. "Habitable Environment Construction Action Plan for Fujian Province 2016" issued by General Office of Fujian Provincial People's Government present proposed a new round of beautiful rural construction program in 2016. Provincial fiscal department also implement the subsidy policy of "substitute subsidies with rewards". With various policy support, Dayu Village's village construction is provided with a solid backing. ${ }^{[2]}$

\subsection{Threats analysis}

\subsubsection{Severe loss of rural labor force}

With acceleration of urbanization, more and more educated and skilled rural "elites" left the countryside, causing great loss rural labor force and the increasing empty-nested phenomenon in rural areas. The investigation shows that among Dayu Village's total population of 409, the resident population is about 225, among which 56 to 64-year-old people take up the largest proportion of $27.11 \%, 0$ to 17 - year-old people take up the second largest proportion of $20.89 \%$, people aged above 65 take up the third largest proportion of $18.67 \%, 46$ to 55 -year-old people occupy 9.33\%, 26 to 35 -year-old people occupy $8.44 \%, 18$ to 25 -year-old people occupy $8.0 \%$, and 36 to 45 -year-old people occupy $7.56 \%$. It follows that people aged above 56 or below 17 are major forces of Dayu Village's resident population and thus cause the discontinuity at age level.

\subsubsection{Inadequate source of construction funds}

The investigation shows, $62.96 \%$ of villagers hope for more convenient public transportation, and $71.23 \%$ of tourists hope for public facilities improvement. But the village committee also expressed their troubles: with only government investment, the realization of beautiful village dream is far from enough. Many facilities are planned but with inadequate construction funds. In research process, it is found that the increase of landscape and infrastructure also increase maintenance expenses. If the problem of inadequate source cannot be solved, follow-up long-term management will not be able to proceed and Dayu Village will have new dept, leading to many problems, negative effects and waste of previous efforts. Ensuring continuous fund for beautiful rural construction is the important guarantee for its sustainable and healthy development.

\section{Suggestions and methods for Dayu Village's beautiful rural construction}

\subsection{Attract talents and build startup platform}

Talent team building is the core of beautiful rural construction. Improvement of agricultural industrialization can't be done without professional talents. In specific, first, deep publicity is needed. Grasp the opportunity of villagers' return for Spring Festival, organize a symposium for returned young people, publicize supportive policies at all levels and the good vision, collect ideas for beautiful rural construction and encourage ambitious young people to return to hometown for startup. Second, preferential measures need to be introduced. Introduce all kinds of preferential measures for young talents to stimulate their passion for beautiful rural construction in a joint effort and attract them to return to hometown for startup. Third, network facilities need to be improved. Boost the construction of information infrastructure, improve network facilities, effectively solve the last one-kilometer network facility problem of the village in order to provide good hardware condition for young people's startup.

\subsection{Change investment philosophy and promote funds integration}

Raising and integrating funds is the guarantee of beautiful rural construction. To realize sustainable development, the village must change its investment philosophy, rely on its own effort, develop in a reasonable way, and raising and integrating funds from various channels and fields. In specific, first, 
collective economy should be developed. Develop collective economy by stimulating resources of the village. Second, participation of all fields should be encouraged. Arouse enthusiasm of repaying one's hometown of local bellwethers of becoming rich, entrepreneurs, migrant worked and people from all walks of life, and mobilize social forces to serve beautiful rural construction. Third, tourism investment should be promoted. Make good use of Dayu Village's eco-tourism resources and distinctive culture of white crane fist to attract investment.

\subsection{Enhance brand awareness and broaden sales channels}

Brand marketing is the extension of beautiful rural construction. In the era of economic new normal, we should enhance brand awareness and make use of brand marketing to broaden sales channels for agricultural and sideline products. Specifically, firstly, a distinctive brand should be created. Brand is a business card for agricultural and sideline products. White Crane Fist culture should be used to create Kongfu Dayu brand, in order to improve the attractiveness, influence and competitiveness of the products, make consumers choose the brand when shopping, broaden the sales channels and realize the value increase of economical industry. Secondly, cooperation mode needs to up graded. Reform and upgrade the specialized cooperative of beautiful rural tourism service in Dayu Village of Yongchun County in order to let specialized cooperative provide unified guidance and supervise villagers to plant agricultural products in a standardized mode as well as to let management, purchase, packaging, sales and operation unified for harvests in production, quality, sales volume. Thirdly, self-help picking should be improved. Self-help picking is a new highlight of the current development of leisure agriculture and rural tourism. It can not only attract tourists, but also sell agricultural and sideline products. Dayu Village should take advantage of its famous fruits such as ponkan, big tangerine, pear Chihuali, orange, etc., improve the self-help picking project in scale, so as to attract tourists to experience pastoral life and promote the development of agricultural and sideline industries.

\subsection{Apply "Internet +" and promote rural tourism}

Development of rural tourism is the key point of beautiful rural construction. Dayu village should closely follow the "Internet + " trend, give full play to the featured cultural function of Whine Crane Fist and vigorously promote its featured country tour. Specifically, firstly, WeChat platform need to be improved. Use words, images, videos and etc. to demonstrate the beautiful rural construction in all aspects on WeChat platform and develop various functions such as policy consultation, tour guide services, investment attraction, interactive exchange, reservation and booking. Secondly, a website should be developed and operated. The website should keep real-time updates to adapt to the development of the tourism website market. The liaison and management of customer relations should be done well. The website shall be vigorously popularized through e-mail, QQ, online travel community and other channels. The Push-Pull strategy should be adopted while the Pull strategy used to attract customers should be valued.

\section{Acknowledgement}

This essay is one of staged achievements of The Construction and Empirical Analysis of Community Governance Capability Evaluation Index System(15CZZ032) in Youth Project of National Social Science Fund Projects.

\section{References}

[1] Minnan net. Yongchun Da Yu Village Sprint China Habitat Environment Example Award [EB/OL].http://www.mnw.cn/quanzhou/yc/xw/1129974.html,2016-3-21; 2017-8-15.

[2] Xu Fayin. The Study on Rural Tourism Development in the Background of Dayu Village "Beautiful Countryside" Construction[D]. Fuzhou: Fujian Agriculture and Forestry University, 2016:30. 